Intestinal, urinary and uterine antispasmodic effects of isoespintanol, metabolite from Oxandra xylopioides leaves

Tatiana C. Gavilánez Buña, Germán A. Colareda , María Inés Ragone, Milena Bonilla , Benjamín A. Rojano, Guillermo R. Schinella , Alicia E. Consolini

PII: S0944-7113(18)30183-1

DOI: 10.1016/j.phymed.2018.06.001

Reference: PHYMED 52522

To appear in: Phytomedicine

Received date: $\quad 7$ February 2018

Revised date: $\quad 21$ April 2018

Accepted date: $\quad 4$ June 2018

Please cite this article as: Tatiana C. Gavilánez Buña, Germán A. Colareda, María Inés Ragone, Milena Bonilla, Benjamín A. Rojano, Guillermo R. Schinella, Alicia E. Consolini , Intestinal, urinary and uterine antispasmodic effects of isoespintanol, metabolite from Oxandra xylopioides leaves, Phytomedicine (2018), doi: 10.1016/j.phymed.2018.06.001

This is a PDF file of an unedited manuscript that has been accepted for publication. As a service to our customers we are providing this early version of the manuscript. The manuscript will undergo copyediting, typesetting, and review of the resulting proof before it is published in its final form. Please note that during the production process errors may be discovered which could affect the content, and all legal disclaimers that apply to the journal pertain. 


\section{Intestinal, urinary and uterine antispasmodic effects of isoespintanol, metabolite from Oxandra xylopioides leaves}

Tatiana C. Gavilánez Buña ${ }^{a, b}$, Germán A. Colareda ${ }^{a}$, María Inés Ragone ${ }^{a, c}$, Milena Bonilla ${ }^{a}$,Benjamín A. Rojano ${ }^{d}$, Guillermo R. Schinella ${ }^{e}$, Alicia E. Consolini

${ }^{a}$ Cátedra de Farmacología, Grupo de Farmacología Experimental y Energética Cardíaca (GFEYEC) y Maestría en Plantas Medicinales,

Departamento de Ciencias Biológicas, Facultad de Ciencias Exactas, Universidad Nacional de La Plata, La Plata, Argentina

${ }^{b}$ Department of Agricultural Sciences and Natural Resources, Technical University of Cotopaxi, La Maná - Ecuador

${ }^{c}$ Consejo Nacional de Investigaciones Científicas y Técnicas de la República Argentina (CONICET)

${ }^{d}$ Laboratorio de Ciencias de los Alimentos, Universidad Nacional de Colombia (sede Medellín), Colombia

${ }^{e}$ Cátedra de Farmacología Básica. Facultad de Ciencias Médicas. Universidad Nacional de La Plata. CIC-PBA, La Plata, Argentina

\footnotetext{
*Corresponding author: Prof. Dra. Alicia E. Consolini Cátedra de Farmacología, Departamento de Ciencias Biológicas, Facultad de Ciencias Exactas, Universidad Nacional de La Plata, 47 y 115 (1900), La Plata, Argentina.

Phone: 54-221-423-5333 int.42

E-mail address: dinamia@biol.unlp.edu.ar
}

Running title: isoespintanol as intestinal, uterine and bladder antispasmodic 


\section{ABSTRACT}

Background: Isoespintanol is a monoterpene isolated from the leaves of Oxandra xylopioides

Diels. (Annonaceae) with antioxidant and antiinflammatory effects. It was of interest to know whether it has antispasmodic effects such as other known drugs, phloroglucinol and trimethoxybenzene, used in therapeutics for treating biliary, urinary and uterine spasms.

Purpose: to assess whether isoespintanol possesses antispasmodic effects on intestine, uterus and bladder.

Study design: A preclinical study was performed in which isoespintanol, phloroglucinol and trimethoxybenzene were evaluated with concentration-contractile response curves (CRC) of carbachol in isolated rat intestine and bladder, and with CRC of serotonin (5-HT) in rat uterus. Moreover, it was assessed whether isoespintanol interferes with $\mathrm{Ca}^{2+}$ influx by making $\mathrm{CRC}$ of $\mathrm{Ca}^{2+}$ in high- $\mathrm{K}^{+}$medium in intestine and bladder.

Results: isoespintanol non-competitively inhibited the CRC of carbachol with affinity constant $(\mathrm{pK})$ of $4.78 \pm 0.09$ in intestine and $4.60 \pm 0.09$ in bladder. Phloroglucinol and trimethoxybenzene were also non-competitive antagonists, but isoespintanol was 8 times more potent than trimethoxybenzene and similarly potent than phloroglucinol in intestine. In bladder, isoespintanol resulted 8 times more potent than trimethoxybenzene. The maximal inhibition of contraction followed the order of isoespintanol > trimethoxybenzene > phloroglucinol in intestine, and isoespintanol > trimethoxybenzene in bladder. Moreover, isoespintanol also completely and non-competitively inhibited the $\mathrm{CRC}$ of $\mathrm{Ca}^{2+}$, with a $\mathrm{pK}$ of $5.1 \pm 0.1$ in intestine, and $4.32 \pm 0.07$ in bladder. In uterus isoespintanol reduced, completely and non-competitively, the contraction produced by 5-HT with pK of $5.05 \pm 0.07$.

Conclusions: Results demonstrate that isoespintanol is a very good intestinal, urinary and uterine antispasmodic, with higher potency than the other drugs used in therapeutics. The mechanism of action of isoespintanol is the interference with $\mathrm{Ca}^{2+}$ influx, at a difference of 
trimethoxybenzene and phloroglucinol.

Keywords: Isoespintanol; Antispasmodic; Intestine; Detrusor; Uterus; Calcium

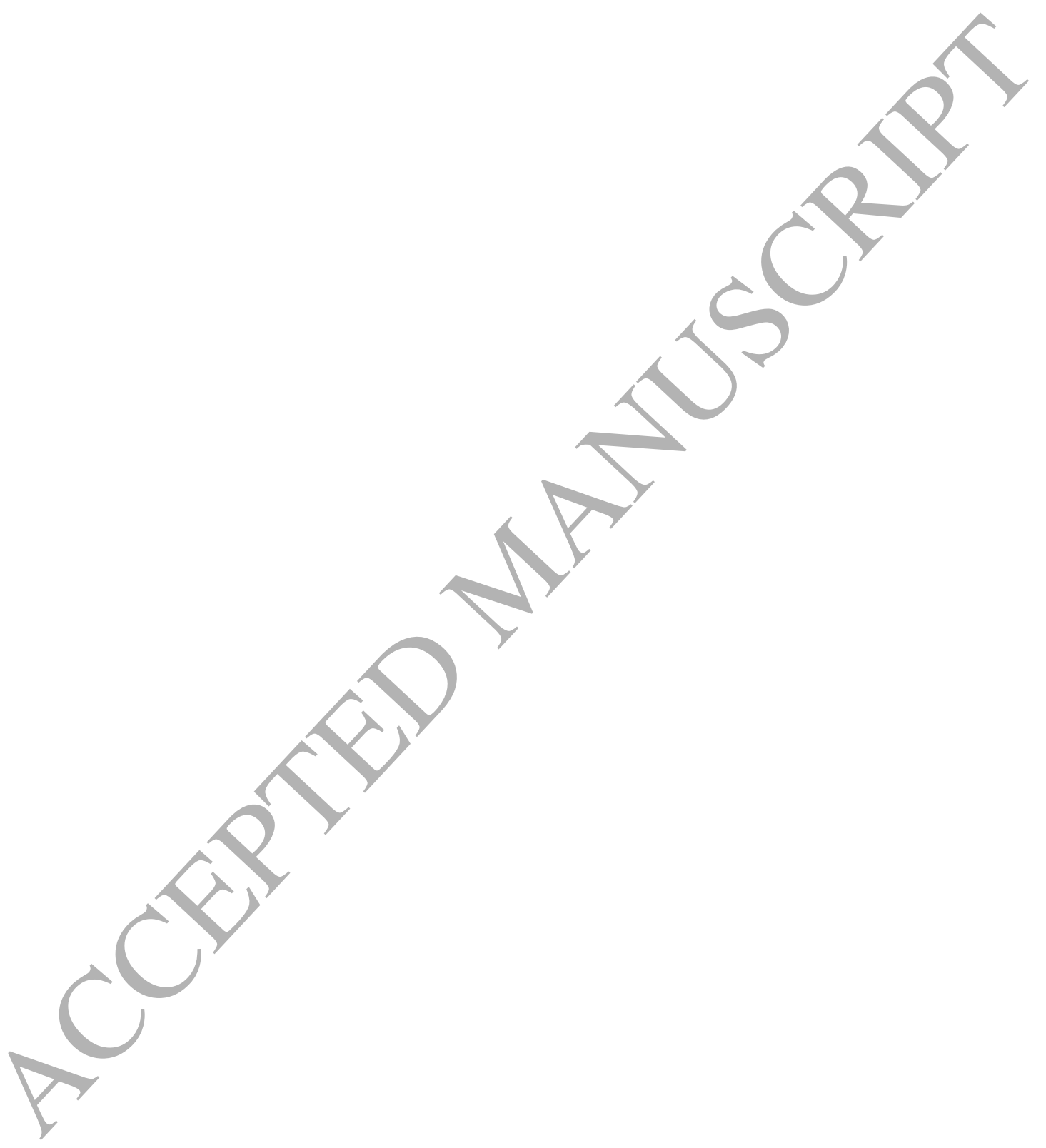




\section{Abbreviations}

BK: big $\mathrm{K}^{+}$channels; Cbl: carbachol; CICUAL: Institutional Comitee for Care of Laboratory Animals; CONICET: National Council of Scientifical and Technical Research; CRC: concentration-contractile response curves; DMSO: dimethylsulphoxide; F: Fisher coefficient for variance statistical test; HPLC: high performance liquid chromatography; 5-HT: serotonin; I.P.: intraperitoneal; NIH: National Institute of Health; pK: affinity constant; SEM: standard error of media.

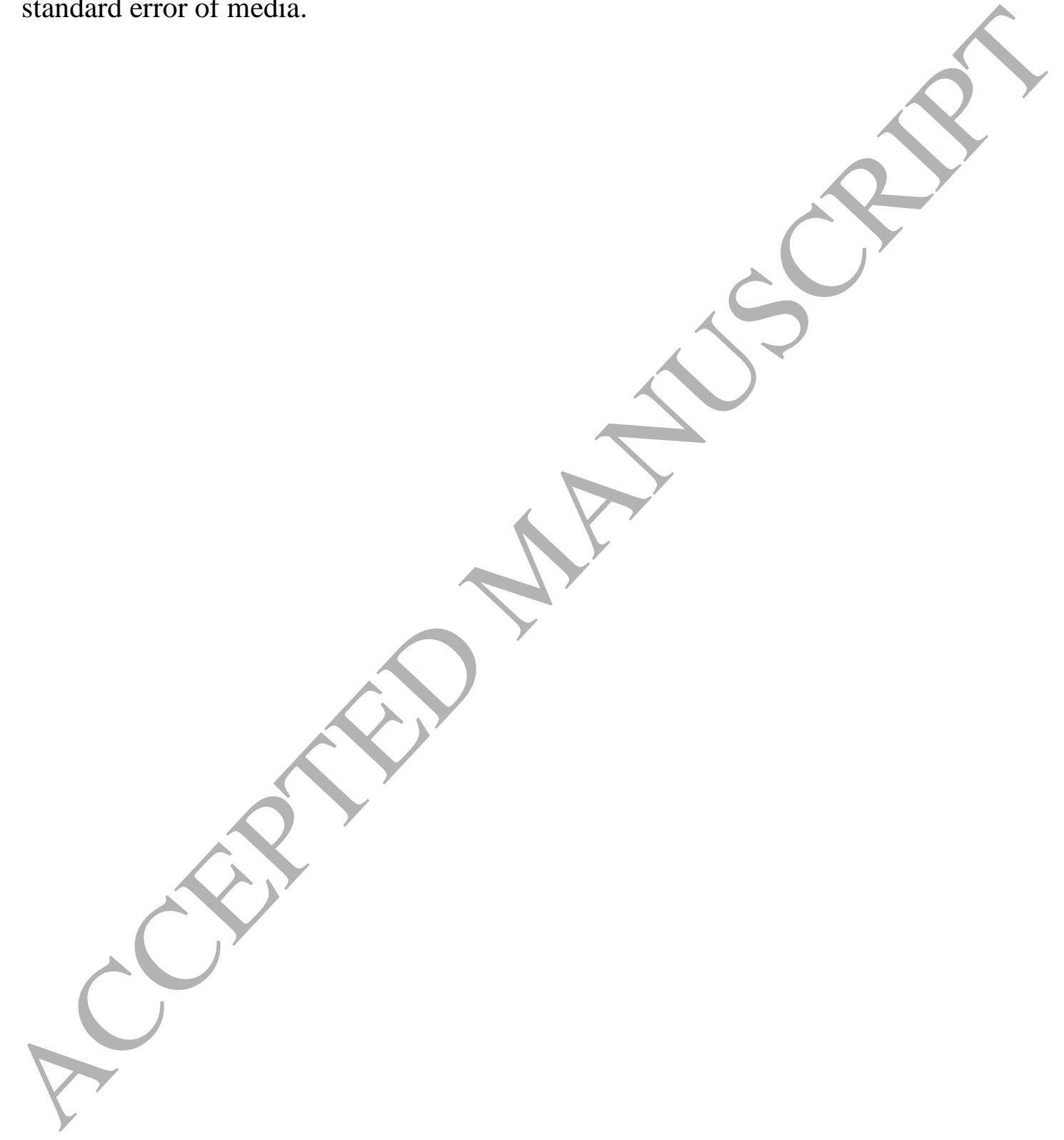




\section{Introduction}

The compound 2-isopropyl-3,6-dimethoxy-5-methylphenol (isoespintanol) is a monoterpene isolated from the leaves of Oxandra xylopioides Diels. (Annonaceae) (Rojano et al., 2007a). Annonaceae plants have several therapeutic properties such as antimalaric and cytotoxic (Tsabang et al., 2012). It was demonstrated that isoespintanol has antiinflammatory, antioxidant and insecticide properties (Rojano et al., 2007a, 2007b, 2008).

Here it was evaluated whether isoespintanol had antispasmodic properties in smooth muscles. Intestinal and uterine aches are caused by the smooth muscles spasms, while the hyperactivity of detrusor becomes in urine loss or bladder incontinence. The usual treatments consist in anticholinergics such as hyoscyamine, glycopyrrolate, oxybutinine or scopolamine, but they have certain incidence of systemic adverse effects and contraindications in glaucoma and prostatic hypertrophy (Brunton et al, 2012). Moreover, two other compounds, phloroglucinol (1,3,5-trihydroxybenzene) and its methoxy-derivative 1,3,5-trimethoxybenzene are used as oral and intramuscular formulations to treat biliary, urinary and uterine spasms, sometimes associated to stones (Boukef et al., 2010). Phloroglucinol has antioxidant and spasmolytic activities with weak anticholinergic properties, it reduced the uretheral ache triggered by stones and facilitated the expulsion (Dellabella et al., 2005). Trimethoxybenzene has a prolonged duration as antispasmodic in comparison to phloroglucinol. It would be important to find new compounds with antispasmodic effects without anticholinergic properties, in order to avoid the typical adverse effects of those antagonists, such as xerostomy, cough associated to the reduction of bronchial secretions, and cardiac palpitations among others.

The aim of this work was to evaluate whether isoespintanol has antispasmodic effects on gastrointestinal, urinary and uterine smooth muscle and the mechanism of action. Moreover, its effects were compared with those of the commercially used phlorogucinol and 
trimethoxybenzene, as positive controls.

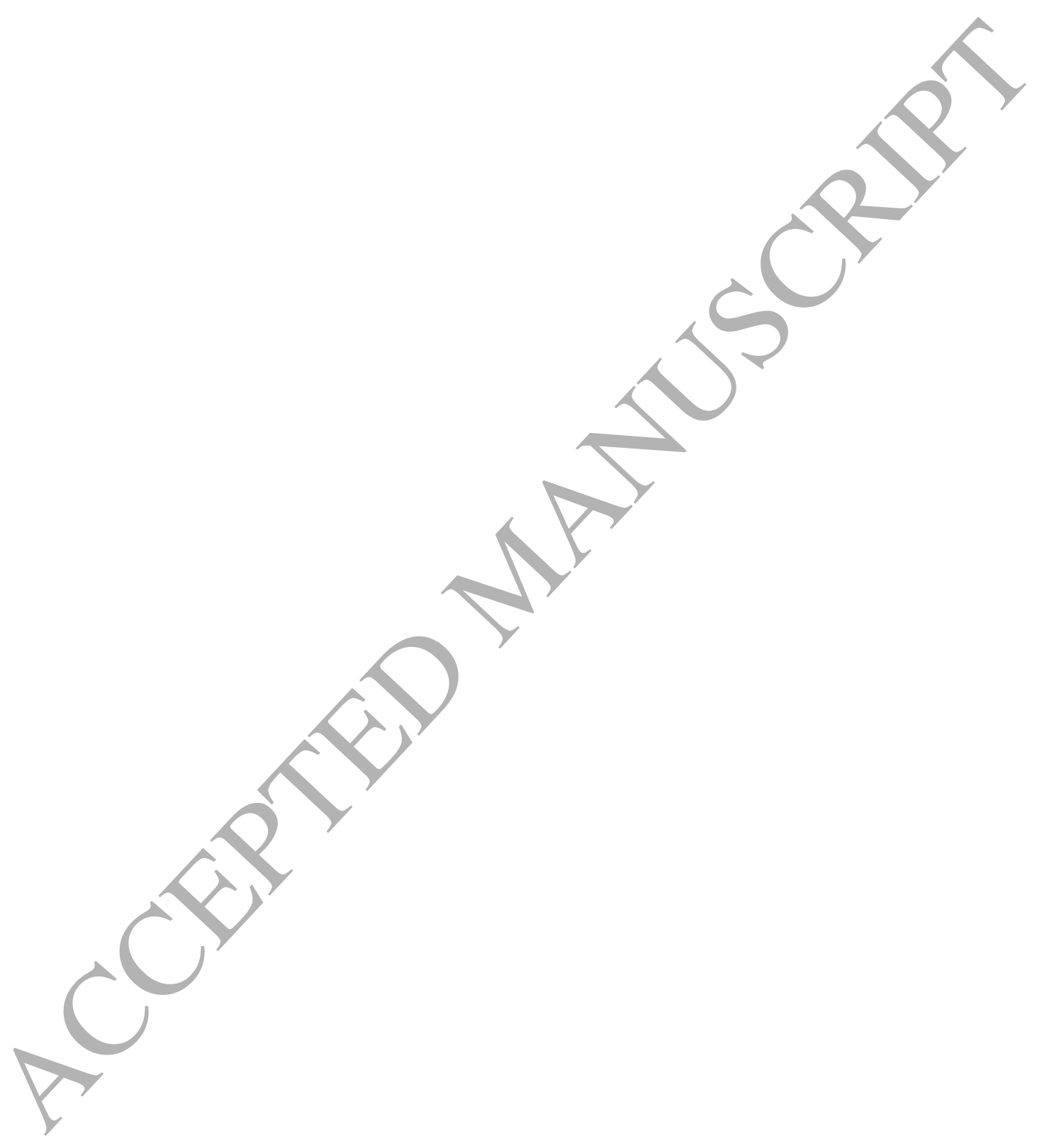




\section{Materials and methods}

\section{Animals}

Sprague-Dawley rats (200-280 g) of both sexes were used. Animals were housed and allowed to have food and water ad libitum in accordance with the internationally accepted principles for the laboratory animal use and care, established by US guidelines (NIH publication \# 85-23 revised in 1996) and principles in the Declaration of Helsinki, according to the Resolution 1047 anexo II-2005, of Consejo Nacional de Investigaciones Científicas y Técnicas (CONICET) de la República Argentina. Rats were subjected to a $12 \mathrm{~h}$ fasting with free access to water before the experiments.

\section{Drugs and solutions}

Isoespintanol (Fig. 1) was previously isolated from the petroleum ether extract of leaves from O. xylopioides by Prof. Dr. Benjamín Alberto Rojano from the Universidad Nacional de Colombia (headquarter Medellín), who/determined the physicochemical properties and structure (Rojano et al., 2007a). The purity of this sample was assessed by HPLC analyses, for which isoespintanol was dissolved in $10 \mathrm{ml}$ of ethanol (at final concentration of $1 \mathrm{~g} / \mathrm{l}$ ) and vortexed for 1 min. Its purity was quantified using a Shimadzu Prominence ${ }^{\circledR}$ modular HPLC equipped with a SPD-M20A diode-array detector according to modified method proposed by Ultee et al. (2002): isocratic elution with methanol/water (60:40); flow rate of $0.8 \mathrm{ml} / \mathrm{min}$; LiChrospher® $100 \mathrm{RP}-18$ column $(5 \mu \mathrm{m}, 250 \times 4 \mathrm{~mm})($ Merck, Darmstadt) thermostated at $35^{\circ} \mathrm{C}$; injection volume $20 \mu \mathrm{l}$. The retention time of isoespintanol was $12.1 \mathrm{~min}$ and its purity $>99 \%$ when monitoring at $277 \mathrm{~nm}$ (see Supplementary material).

For the present evaluation, the purified crystalline solid of isoespintanol was dissolved in dimethylsulphoxide (DMSO) at concentrations of $0.3,1,3$ and $10 \mathrm{mM}$ as mother solutions. Phloroglucinol (Sigma-Aldrich, St Louis, MO, USA) was dissolved in water at concentrations 
of $0.1,0.3,1,3,10$ and $30 \mathrm{mM}$. Trimethoxybenzene (Sigma-Aldrich) was dissolved in DMSO at concentrations of $0.1,0.3,1,3,10$ and $30 \mathrm{mM}$. Verapamil chloride (ICN Biomedicals Inc., Horsha, PA, USA) was prepared in concentrations of $0.01,0.03,0.1,0.3$ and $1 \mathrm{mM}$. Carbamylcholine (carbachol, Sigma-Aldrich), serotonin (5-HT, Sigma-Aldrich) and adrenaline (in ampules at $1 \mathrm{~g} / \mathrm{ml}$ from BIOL, Instituto Biológico Argentino S.A.I.C. Buenos Aires, Argentina) were prepared in a series of 1, 2, 7, 20, 70, 200, 700 and 1000 $\mu \mathrm{g} / \mathrm{ml}$ in water.

In order to reach the desired concentration all drugs solutions were finally diluted in the chamber for isolated organs at $1 / 100$. These physiological media were the Tyrode's solution for intestine (composition, in $\mathrm{mM}, 150 \mathrm{NaCl}, 2.7 \mathrm{KCl}, 2 \mathrm{MgCl}_{2}, 12 \mathrm{NaHCO}_{3}, 0.4 \mathrm{PO}_{4} \mathrm{H}_{2} \mathrm{Na}$, 5.5 D-glucose, $1.8 \mathrm{CaCl}_{2}, \mathrm{pH} 8.2$ ), Tyrode's-0Ca by eliminating $\mathrm{CaCl}_{2}$ and Tyrode's-0Ca-40 $\mathrm{mM} \mathrm{K}{ }^{+}$by adding $0.6 \mathrm{ml} \mathrm{KCl} 10 \%$ to $20 \mathrm{ml}$ Tyrode's-0Ca (Ragone et al., 2007), the modified Tyrode's solution with $2.5 \mathrm{mM} \mathrm{CaCl}_{2}$ for bladder strips (Hamada et al., 1997), or De Jalon's solution for uterine tissues (composition, in mM, 9.0 NaCl, 0.5 $\mathrm{NaHCO}_{3}, 0.5 \mathrm{D}$ glucose, $0.4 \mathrm{KCl}, 0.1 \mathrm{CaCl}_{2}$ ) (Livingstone and Livingstone, 1970; Kitchen, 1984).

\section{Pharmacological studies}

Biological preparations and contractile measurements

Rats were anesthetized with urethane (1.5 g/kg via I.P.) (Livingstone and Livingstone, 1970) according to the approved protocol Nr. 015/2015 from the Institutional Commitee for the Care of Laboratory Animals (CICUAL) of Facultad de Ciencias Exactas, Universidad Nacional de La Plata (UNLP). Then, rats were quickly sacrificed by opening the thorax and abdomen. The duodenum and ileum (about $2 \mathrm{~cm}$ long) were excised and mounted in $20 \mathrm{ml}$ chambers for isolated organs containing Tyrode's solution at $37^{\circ} \mathrm{C}$ and constantly oxygenated with air bubbling, as in previous works (Ragone et al., 2007; Matera et al., 2012; Blanco et 
al., 2013; Jiménez Hernández et al., 2018). The excised bladder was divided in 3 or 4 longitudinal slices respectively mounted in chambers with Tyrode's solution similarly to the intestinal portions. Both uterine horns were excised, divided in 4 parts and immersed in De Jalon's solution in chambers at $32^{\circ} \mathrm{C}$ bubbled with air (Kitchen, 1984).

Each preparation was longitudinally connected to an isometric transducer, either FORT100 (World Precision Instruments (WPI), Sarasota, FL, USA) for intestine and bladder, or MLT0210/A, (ADInstruments, New South Wales, Australia) for uterine tissues. Tissues were equilibrated for at least $45 \mathrm{~min}$ at $1 \mathrm{~g}$ of pre-load. The signals were simultaneously amplified by a 4-channels preamplifier (WPI) and recorded by the Eagle software, or by a 2channels Power Lab system (ADInstruments), respectively.

\section{Concentration-contractile response curves with carbachol or serotonin}

Concentration-response curves (CRC) with the agonist carbachol were done in intestine and bladder portions by cumulatively adding the solutions to the chamber (obtaining final concentrations of $0.01,0.03,0.1,0.3,1,3$ and $10 \mu \mathrm{g} / \mathrm{ml}$ ) first in the absence (control) and then in the presence of the vehicle or a unique concentration of the antagonist $(3,10,30$ and $100 \mu \mathrm{M}$ of isoespintanol; 1, 3, 10, 30, 100 and $300 \mu \mathrm{M}$ of phloroglucinol; 1, 3, 10, 30, 100 and $300 \mu \mathrm{M}$ of trimethoxybenzene; or $0.1,1$ and $10 \mu \mathrm{M}$ of verapamil). The contractile effect of each agonist concentration was expressed as percentage of the maximal contraction of tissue obtained with the second control-CRC (\% Emax, percentage of maximal effect). The antagonist concentrations were assessed by individually adding them $5 \mathrm{~min}$ before the respective $\mathrm{CRC}$, in growing order.

In uterine tissue the baseline had spontaneous and large phasic contractions, and the consecutive $\mathrm{CRC}$ of the agonist 5-HT were done by reaching cumulative final concentrations of $0.01,0.03,0.1,0.3,1$ and $3 \mu \mathrm{g} / \mathrm{ml}$. The effect of each 5 -HT concentration was measured as 
the maximal amplitude of the phasic contractions and expressed as percentage of the maximal contraction in the control CRC (that obtained in the absence of antagonist).

\section{Concentration-contractile response curves with $\mathrm{CaCl}_{2}$}

After stabilization of intestines, consecutives $\mathrm{CRC}$ of $\mathrm{Ca}^{2+}$ were done in the depolarizing media of Tyrode- $0 \mathrm{Ca}-40 \mathrm{mM} \mathrm{K}^{+}$. Each CRC was obtained in the chambers of 20 $\mathrm{ml}$ by cumulatively adding $\mathrm{CaCl}_{2}(0.2 \mathrm{ml}$ of the solutions with $0.882,1.764,5.3,18.5,53$ and $185 \mathrm{mg} / \mathrm{ml}$ ) to reach concentrations of $0.079,0.238,0.636,2.14,6.44$ and $21.44 \mathrm{mM}$, first in the absence (control) and then in the presence of unique, consecutive and growing concentrations of the antagonists. The contractile effect of each $\mathrm{Ca}^{2+}$ concentration was expressed as percentage of the maximal contraction of tissue obtained in the second control of $\mathrm{Ca}^{2+}-\mathrm{CRC}$ (as \% Emax). Each antagonist was added $5 \mathrm{~min}$ before the depolarization with high- $\mathrm{K}^{+}$in Tyrode's-0Ca and remained throughout the $\mathrm{Ca}^{2+}-\mathrm{CRC}$.

Concentration-relaxing response curves of adrenaline and isoespintanol in uterus

After contracting uterine tissue with $2 \mu \mathrm{g} / \mathrm{ml} 5-\mathrm{HT}$, relaxation was obtained by cumulative addition of adrenaline to obtain steps of final concentrations of $0.01,0.03,0.1$, $0.3,1,3$ and $10 \mu \mathrm{g} / \mathrm{ml}$. Similarly, relaxation was obtained by cumulatively adding isoespintanol to obtain steps of final concentrations of $3,13,43$ and $143 \mu \mathrm{M}$, and as a negative control it was added the vehicle (DMSO) in steps.

\section{Pharmacological parameters calculation}

From the CRC, the concentration to $50 \%$ of maximal effect of the agonist $\left(\mathrm{pEC}_{50}=-\right.$ $\log \mathrm{EC}_{50}$, expressed in $\left.\mathrm{M}\right)$ and the affinity constant $\left(\mathrm{pK}_{\mathrm{B}^{\prime}}\right)$ of the non-competitive antagonists (isoespintanol, phloroglucinol, trimethoxybenzene and verapamil) were calculated. This 
parameter represents the affinity of the non-competitive metactoid antagonist for its cellular site of interaction (van Rossum, 1963; Kenakin, 2014). The $\mathrm{pK}_{\mathrm{B}^{\prime}}$ was calculated using the following equation: $-\log K_{B^{\prime}}=-\log \left[B^{\prime}\right]+\log \left[\left(E_{A}-E_{A B^{\prime} m a x}\right) /\left(E_{A}-E_{A B^{\prime}}\right)-1\right]$, where [B'] is the concentration of the non-competitive antagonist (in $\mathrm{M}$ ), and $\mathrm{E}_{\mathrm{A}}, \mathrm{E}_{\mathrm{AB}}$ ' and $\mathrm{E}_{\mathrm{AB}}{ }^{\prime} \max$ are the maximal effects of the agonist respectively in the absence (A) and in the presence of the antagonist ( $\mathrm{AB}^{\prime}$ ) and under its maximal concentration (AB'max), considering complete blockade with $E_{A B^{\prime} \max }$ as zero. The $\mathrm{pEC}_{50}$ and $\mathrm{pK}_{\mathrm{B}^{\prime}}$ were calculated from each individual series of CRC done in a tissue, and then the mean \pm SEM was calculated.

Moreover, the values of $\mathrm{pD}_{2}^{\prime}$ were calculated by using the Gaddum method (Kenakin, 2014). This method compares two concentrations with the same effect of the agonist (carbachol) in the absence ([A]) and the presence of the antagonist ([A $\left.]_{\mathrm{B}}{ }^{\prime}\right)$. Then, it is possible to obtain the linear regression between the several paired values of $1 /[\mathrm{A}]_{\mathrm{B}}{ }^{\prime}$ versus $1 /[\mathrm{A}]$ and calculate the Gaddum equation as: $K_{B}=\left[B^{\prime}\right] /($ slope -1$)$, where $\left[B^{\prime}\right]$ is the antagonist concentration (in $\mathrm{M}$ ), and its affinity is $p K_{B}=-\log K_{B^{\prime}}$. Fig. 3 shows the calculation of isoespintanol affinity (as $p K$ ) from the CRC obtained in intestine (Fig. 2a).

Also, the $\mathrm{IC}_{50}$ (in $\mu \mathrm{M}$ ) was calculated by interpolation on the curve $\mathrm{E}$ vs [B'] built from the effects of a CRC series done in each individual tissue, at a constant agonist concentration, generally which triggers the maximal effect, as previously described (Blanco et al., 2013). A comparison among $\mathrm{IC}_{50}$ of drugs was done in order to estimate differences in potency, which is defined as the ratio between the concentrations needed to reach the same effect.

\section{Statistical methods}

All results are expressed as means \pm SEM (standard error of media). The statistical comparison was done by two-way ANOVA test for multiple comparisons, where the variables 
were: treatment and $-\log$ [agonist]. The ANOVA results were expressed by $\mathrm{F}$ (Fisher coefficient for variance statistical test) and its significance $(p)$. After the ANOVA, the Bonferroni's a posteriori test for comparison with the respective point of the control CRC was done. The statistical analyses were done with Graph Pad Prism 4.0 software. The oneway ANOVA for comparing more than two values, and the Student's $t$-tests were also used when necessary. In all tests, $p$ values $<0.05$ were considered significant. 


\section{Results}

\section{Antispasmodic effects on intestinal muscles}

Isoespintanol was a non-competitive antagonist of the $\mathrm{CRC}$ of carbachol $\left(\mathrm{pEC}_{50}=\right.$ $5.84 \pm 0.06)$ since it reduced the maximal effects dependently on its concentration (Fig. 2a). Table 1 shows the values of isoespintanol affinity calculated as $\mathrm{pD}^{\prime} 2$ by two methods, traditional and Gaddum's (showed in Fig. 3). As it was expected, the affinity constant was independent on the method, the agonist or the antagonist concentration. The $\mathrm{pD}^{\prime} 2=\mathrm{pK}$ was $4.78 \pm 0.09$, while the $\mathrm{IC}_{50}$ of isoespintanol resulted $12.5 \pm 4.2 \mu \mathrm{M}(\mathrm{n}=8)$. Similar behavior showed the other known antispasmodics phloroglucinol $\left(\mathrm{pD}^{\prime} 2=\mathrm{pK}=4.77 \pm 0.12, \mathrm{IC}_{50}=7.1\right.$ $\pm 1.31 \mu \mathrm{M}, \mathrm{n}=4)$ and trimethoxybenzene $\left(\mathrm{pD}^{\prime} 2=\mathrm{pK}=4.39 \pm 0.09, \mathrm{IC}_{50}=152 \pm 33 \mu \mathrm{M}, \mathrm{n}=\right.$ 5) (Fig. 2b and 2c). Fig. 2d compares the inhibition curves obtained from the CRC shown in $\mathrm{a}, \mathrm{b}$ and $\mathrm{c}$ for isoespintanol, phloroglucinol and trimethoxybenzene and their $\mathrm{IC}_{50}$. It can be concluded that isoespintanol showed similar potency than phloroglucinol and both of them were more potent than trimethoxybenzene.

\section{Antispasmodic effects on bladder}

Isoespintanol also was a non-competitive antagonist of the $\mathrm{CRC}$ of carbachol $\left(\mathrm{pEC}_{50}=\right.$ $5.70 \pm 0.11, \mathrm{n}=5$ ) on bladder trips (Fig. $4 \mathrm{a}$ ). The affinity of isoespintanol was calculated as $\mathrm{pD}^{\prime} 2=\mathrm{pK}=4.60 \pm 0.09$ (see Table 1 ), while the $\mathrm{IC}_{50}$ of isoespintanol resulted $38.64 \pm 3.1$ $\mu \mathrm{M}$. Similar behavior showed trimethoxybenzene $\left(\mathrm{pD}^{\prime} 2=\mathrm{pK}=4.01 \pm 0.12\right)$, although it did not inhibit the contraction up to $50 \%$, by which it was calculated the $\mathrm{IC}_{40}=231 \pm 36 \mu \mathrm{M}$ (n $=$ 4) (Fig. 4b). In contrast, phloroglucinol did not inhibit the CRC of carbachol (Fig. 4c, n=6). Considering that the non-competitive inhibition of isoespintanol could be due to inhibition of $\mathrm{Ca}^{2+}$ influx to the smooth muscle of bladder, we compared these results with the effect of the known $\mathrm{Ca}^{2+}$ channels blocker verapamil, as a positive control. Verapamil also non- 
competitively inhibited the CRC of carbachol (Fig. 4d), with an $\mathrm{IC}_{50}$ of $0.83 \pm 0.05 \mu \mathrm{M}(\mathrm{n}=$ 4), and $\mathrm{pD}^{\prime} 2=\mathrm{pK}=5.80 \pm 0.13$ or $\mathrm{pK}=6.06 \pm 0.05$, according to the method (Table 1). Fig. 5a shows that isoespintanol was about 40 times less potent than verapamil but about 6 times more potent than trimethoxybenzene.

Moreover, isoespintanol was assessed in the tonic contracture of bladder strips developed by $0.7 \mu \mathrm{g} / \mathrm{ml}$ carbachol, to which relaxed up to about $66 \%$ of the initial tone with a $\mathrm{IC}_{50}$ of $11.5 \pm 0.5 \mu \mathrm{M}(\mathrm{n}=4)$ (Fig. $\left.5 \mathrm{~b}\right)$, after substracting the relaxation due to the vehicle, DMSO (less than $24 \%$ of tonic contraction). Also, isoespintanol reduced the phasic contractions induced by electrical field stimulation, with a $\mathrm{IC}_{50}$ of $35.1 \pm 20 \mu \mathrm{M}(\mathrm{n}=4)$ to reach a maximal inhibition of about $44 \%$ of the phasic contraction.

\section{Antispasmodic effects on uterus}

Isoespintanol was a non-competitive inhibitor of the 5-HT CRC $\left(\mathrm{pEC}_{50}=6.71 \pm 0.07, \mathrm{n}=\right.$ 6) in uterus (Fig. 6a). The affinity of isoespintanol was calculated as $\mathrm{pD}^{\prime} 2=\mathrm{pK}=5.05 \pm 0.06$ (see Table 1), while the $\mathrm{IC}_{50}$ of isoespintanol resulted $13.7 \pm 2.7 \mu \mathrm{M}$. Moreover, isoespintanol relaxed the tonic contracture of uterus developed by $1 \mu \mathrm{g} / \mathrm{ml} 5-\mathrm{HT}$. After substracting the relaxation due to the vehicle DMSO, isoespintanol relaxed uterus in about $55 \%$ of the tonic contracture, with a $\mathrm{IC}_{50}$ of $7.10 \pm 1.16 \mu \mathrm{M}$ (Fig. $6 \mathrm{~b}$-d). Isoespintanol was less potent than adrenaline, which relaxed completely $(96 \pm 2 \%)$ the tonic contracture of 5 -HT, with a $\mathrm{IC}_{50}$ of $1.00 \pm 0.31 \mu \mathrm{M}$ (Fig. 6d).

\section{Antispasmodic mechanisms on smooth muscle}

In order to evaluate whether the antispasmodic non-competitive effect of isoespintanol was due to inhibition of calcium influx to the smooth muscle, its effects on CRC of $\mathrm{Ca}^{2+}$ were assessed in intestinal and bladder muscles under high $\left[\mathrm{K}^{+}\right]$depolarization (Tyrode-0 Ca-40 
$\mathrm{mM} \mathrm{K}$ ). In both smooth muscles isoespintanol was a non-competitive antagonist of $\mathrm{Ca}^{2+}$ influx (Fig. 7a and b). In intestinal muscle the $\mathrm{Ca}^{2+}-\mathrm{CRC}$ showed a $\mathrm{pEC}_{50}$ of $2.67 \pm 0.04(\mathrm{n}=$ 11) while the affinity constant of isoespintanol resulted $\mathrm{pD}^{\prime} 2=\mathrm{pK}=5.10 \pm 0.1(\mathrm{n}=11)$ and $\mathrm{pK}=4.65 \pm 0.15$ by the Gaddum method (Table 1 ). The $\mathrm{IC}_{50}$ of isoespintanol was $35.6 \pm 15.9$ $\mu$ M. In bladder muscles, the $\mathrm{Ca}^{2+}-\mathrm{CRC}$ exhibited a $\mathrm{pEC}_{50}$ of $2.77 \pm 0.09(\mathrm{n}=4)$, while the non-competitive affinity constant of isoespintanol was calculated as $\mathrm{pD}^{\prime} 2=\mathrm{pK}=4.32 \pm 0.07$ $\mu \mathrm{M}(\mathrm{n}=11)($ Table 1$)$. The $\mathrm{IC}_{50}$ of isoespintanol was $98.6 \pm 11.86 \mu \mathrm{M}$. Contrarily, trimethoxybenzene did not inhibit the $\mathrm{Ca}^{2+}-\mathrm{CRC}$ proportionally to its concentration (Fig. $7 \mathrm{c}$ ), by which it is not considered antagonist of $\mathrm{Ca}^{2+}$ influx. Table 1 also shows that the $\mathrm{pK}$ of verapamil was higher of the isoespintanol $\mathrm{pK}$ in both intestine and bladder with the agonists and $\mathrm{Ca}^{2+} \mathrm{CRC}^{\prime} \mathrm{s}$. 


\section{Discussion}

This work demonstrates that isoespintanol has antispasmodic effects on intestinal, bladder and uterine smooth muscles, with higher potency than trimethoxybenzene, which is used in oral or intramuscular formulations to treat biliary, urinary, intestinal and uterine spasms consequent to stones (Boukef et al., 2010). So, isoespintanol appears as a promisory therapeutic agent similarly potent to phloroglucinol against intestinal spasms, more potent than trimethoxybenzene in bladder, and also antispasmodic in uterus.

Our results obtained in isolated organs of rat showed that isoespintanol has better properties than classic antiespasmodics as hyoscine, used for intestinal and uterine spasms, since it was not antimuscarinic but a non-competitive antagonist, as well as trimethoxybenzene and phloroglucinol. Because of that, isoespintanol offers an advantage over anticholinergic drugs that is to lack the adverse effects such as xerostomy and palpitations. Comparing the other drugs used for treating urinary spasms, it was reported that the methoxy substituents of trimethoxybenzene extend the effect of phloroglucinol and increase the potency (Dellabella et al., 2005; Goswami et al., 2016; Zhuang et al., 2003). Nevertheless, we did not find antispasmodic effects of phloroglucinol in bladder, while other report described very weak inhibition of phloroglucinol on normal intestinal peristalsis under spasms (Cahen, 1962).More recently, a meta-analysis of clinical reports concluded that only one randomized clinical trial found that phloroglucinol was superior to placebo treating abdominal pain, and that there is insufficient data to justify the wide-spread prescription of phloroglucinol (Blanchard et al., 2018). Moreover, there are medicines with anticholinergic and calcium antagonist properties to synergistically reduce the anormal contractions of bladder due to inestability or hiperactivity of detrusor (Sugaya et al. 2012). To this therapeutic group belong oxybutinine and propiverine, which have strong anticholinergic activity but weak effect as calcium channels blocker (Hamada et al., 1997; Sakakibara et al. 2016). Other 
antimuscarinic drugs such as tolterodine and imidafenacin are effective because also reduce the bladder epithelial cells ATP release, which contributes to contractile hyperactivity (Nishijima et al. 2009). In comparison to all these drugs, isoespintanol has good antispasmodic properties, and it was a non-competitive antagonist in the three types of smooth muscle, independently on the receptor that triggers the contraction (M3 in the intestine and detrusor, and 5-HT2 in uterus) and on the tissue differential characteristics (total receptors number and efficiency of stimulus-response coupling) (Kenakin, 2014). The affinity constant ( $\mathrm{pK}$ or $\mathrm{pD}^{\prime 2}$ ) of isoespintanol estimated in uterine tissue was not significantly different to that obtained in intestine and in bladder (Table 1). Also, a good correspondence was found between classic method of pD’2 based in Ariens theory (Van Rossum, 1963) and $\mathrm{pK}_{\mathrm{B}}^{\prime}$ obtained by using the Gaddum method (Kenakin, 2014) as showed in Table 1. These results suggested that isoespintanol had the same binding site and mechanism on the three types of smooth muscle, so we assessed whether it was the L-type $\mathrm{Ca}^{2+}$ channels.

The most important cellular event for triggering contraction in all smooth muscles is the $\mathrm{Ca}^{2+}$ influx trough the voltage-dependent L-type channels. Our results showed that isoespintanol was also a non-competitive antagonist in the $\mathrm{CRC}$ of $\mathrm{Ca}^{2+}$ on intestine and bladder, while trimethoxybenzene did not interfere with $\mathrm{Ca}^{2+}$ influx. So, the potency of isoespintanol to interfere with $\mathrm{Ca}^{2+}$ influx was compared with verapamil, a known frequencydependent $\mathrm{Ca}^{2+}$-channels blocker. Here we showed that verapamil also was a non-competitive antagonist of the carbachol-CRC in bladder, as previously we have shown in intestinal smooth muscle on the carbachol and $\mathrm{Ca}^{2+} \mathrm{CRC}^{\prime}$ 's (Blanco et al., 2013). This behavior is due to the binding of verapamil inside of the channel, which is different to the dihydropyridines calcium blockade, since they bind to the external $\mathrm{Ca}^{2+}$ site and compete with this ion (Spedding, 1985). Verapamil showed higher affinity than isoespintanol, since its $\mathrm{pD}^{\prime 2}$ (or $\mathrm{pK}$ ) was about 6 in both $\mathrm{Ca}^{2+}$ and acethylcholine CRC's on intestinal muscle (Blanco et al. 2013), as well as 
in carbachol CRC on bladder (Fig. 4d). All these values agree with previous reports that estimated an affinity of about $1 \mu \mathrm{M}$ for verapamil (Ishii et al., 1985). Isoespintanol was 9 times less potent than verapamil in intestine and 40 times less in bladder (comparing the $\mathrm{IC}_{50}$ ). There are differences in the $\mathrm{IC}_{50}$ of isoespintanol in bladder estimated from the inhibition of the tonic contracture induced by carbachol (about $11 \mu \mathrm{M}$ ) and that estimated from the phasic contractions induced by electrical stimulation or by the CRC of carbachol (about 35-40 $\mu \mathrm{M}$ ). It is known that tonic contracture of smooth muscles are completely dependent on $\mathrm{Ca}^{2+}$ channels opening, while phasic contraction could have other contributions in some smooth muscles (Zhao et al. 1993). In the phasic spikes of bladder occurs the activation followed by inactivation of $\mathrm{K}^{+}$channels (mostly BK), which mantain the resting potential with alternancy between activation and repolarization of L-type $\mathrm{Ca}^{2+}$ channels, generating the spontaneous automaticity (Petkov, 2011; De la Fuente et al., 2014; Philyppov et al., 2016). The effect of isoespintanol could also be due to direct activation of $\mathrm{K}^{+}$channels. Nevertheless, the fact that isoespintanol was also a non-competitive antagonist on the $\mathrm{Ca}^{2+}-\mathrm{CRC}$ allows to reject this hypothesis, because in a high- $\mathrm{K}^{+}$medium the $\mathrm{K}^{+}$-channels openers are inactive as relaxants (Quast, 1993). So, the differences in the isoespintanol sensitivity in bladder could be due to differences in either, the number of $\mathrm{Ca}^{2+}$ channels involved in tonic and phasic contractions or their activation threshold. Moreover, the higher antispasmodic potency of isoespintanol than that of phloroglucinol and trimethoxybenzene especially in bladder, may be dependent on the fact that only isoespintanol was a $\mathrm{Ca}^{2+}$-non-competitive antagonist.

The uterine muscle has also spontaneous activity with contractile spikes of great amplitude, in which $\mathrm{K}^{+}$channels play an important role to activate $\mathrm{Ca}^{2+}$ channels (Smith et al. 2007). Isoespintanol relaxed the tonic contraction induced by 5-HT and non-competitively inhibited the CRC of 5-HT in uterus. However, isoespintanol relaxed the tonic contraction (up to $45 \%$ ) less than adrenaline (up to $96 \%$ of contraction) and it was 7 times less potent than the 
$\beta$-adrenergic agonist. These differences agree with the different mechanisms of action of adrenaline (activation of PKA by the $\beta 2$-receptor with affinity estimated in about $0.01 \mu \mathrm{M}$ ) and isoespintanol (interference with $\mathrm{Ca}^{2+}$ influx with affinity estimated in about $10 \mu \mathrm{M}$ ).

\section{Conclusions}

Isoespintanol demonstrated to be a good antispasmodic in rat intestine, bladder and uterus, which non-competitively antagonized the $\mathrm{CRC}$ of carbachol and serotonin with similar $\mathrm{pK}$ (about 5) and $\mathrm{IC}_{50}$ between 7 and $38 \mu \mathrm{M}$. It also non-competitively interfered with the $\mathrm{Ca}^{2+}$ influx to smooth muscle as well as verapamil does, although isoespintanol was less potent than this drug. So, isoespintanol appears as a promisory therapeutic agent in comparison to other therapeutic drugs. Isoespintanol was similarly potent to phloroglucinol against intestinal spasms, while both of them were 8 times more potent than trimethoxybenzene. In bladder, isoespintanol was 40 times less potent than verapamil but also about 6 times more potent than trimethoxybenzene, while phloroglucinol did not exhibit antispasmodic effect against carbachol. Moreover, isoespintanol reduced the phasic and tonic serotonin-dependent contractions in uterus, although it was about $50 \%$ less relaxant and 7 times less potent than adrenaline. Although more studies must be done in human tissues, it is important to note that generally the less potent drugs are used in therapeutics, in order to gain selectivity among the different tissues and to reduce adverse effects. So, isoespintanol represents a new pharmacological tool with good perspectives for the treatment of intestinal and uterine spasms as well as in the hyperactivity of detrusor. 


\section{Acknowledgments}

To the Universidad Nacional de La Plata.

\section{Funding}

This work was supported by the Universidad Nacional de La Plata (grants UNLP-11-648 and UNLP-11-795) and by funds from the postgraduate courses of Master in Medicinal Plants.

\section{Conflict of interest}

We wish to confirm that there are no conflicts of interest associated with this publication and there has been no significant financial support for this work that could have influenced its outcome. 


\section{References}

Blanco, M., Colareda, G.A., Baren, C., Bandoni, A., Ringuelet, J., Consolini, A.E., 2013. Antispasmodic effects and composition of the essential oils from two South American chemotypes of Lippia alba. J. Ethnopharmacol. 149, 803-809.

Blanchard, C., Pouchain, D., Vanderkam, P., Perault-Pochat, M.C., Boussageon, R., Vaillant-Roussel, H. 2018. Efficacy of phloroglucinol for treatment of abdominal pain: a systematic review of literature and meta-analysis of randomised controlled trials versus placebo. Eur. J. Clin. Pharmacol. doi: 10.1007/s00228-018-2416-6.

Boukef, R., Claessens, Y.E., Bouida, W., Grissa, M.H., Beltaief, K., Trimech, M.N., Kerkeni, W., Boudhib, L., Nouira, S., 2010. Phloroglucinol as an adjuvant analgesic to treat renal colic. Am. J. Emerg. Med. 28, 720-723.

Brunton, L.L., Chabner, B.A., Knollmann, B.C., 2012. Goodman and Gilman. Las Bases Farmacológicas de la Terapéutica, twelfth ed., Mc Graw Hill Interamericana, Mexico, pp. 225-235.

Cahen, R., 1962. Phloroglucinol: a pharmacological reevaluation. I. Smooth muscle relaxing properties. Arch. Int. Pharmacodyn. Ther. 138, 311-319.

De la Fuente, J., Fernández, A., Cuevas, P., Gonzáles, R., Xiang, M., Angulo, J., 2014. Stimulation of large-conductance calcium-activated potassium channels inhibits neurogenic contraction of human bladder from patients with urinary symptoms and reverses acetic acid-induced bladder hyperactivity in rats. Eur. J. Pharmacol. 735, 68-76.

Dellabella, M., Milanese, G., Muzzonigro, G., 2005. Randomized trial of the efficacy of tamsulosin, nifedipine and phloroglucinol in medical expulsive therapy for distal ureteral calculi. J. Urol. 174, 167-172.

Goswami, S.K., Gangadarappa, S.K., Vishwanath, M., Razdan, R., Jamwal, R., Bhadri, N., Inamdar, M/N., 2016. Antioxidant potential and ability of phloroglucinol to decrease formation of advanced glycation end products increase efficacy of sildenafil in diabetesinduced sexual dysfunction of rats. J. Sex. Med. 4, 104-112.

Hamada, K., Sasaki, Y., Taniguchi, N., Fukui, H., Miyatsuka, Y., Kimura, Y., Ukai, Y., Yoshikuni, Y., Kimura, K., 1997. Anticholinergic and calcium antagonistic activities of NS-21 contribute to the inhibition of rat urinary bladder contractions. Gen. Pharmacol. 5, 771-778.

Ishii, K., Taira, N., Yanagisawa, T., 1985. Differential antagonism by Bay K 8644, a dihydropyridine calcium agonist, of the negative inotropic effects of nifedipine, 
verapamil, diltiazem and manganese ions in canine ventricular muscle. Br. J. Pharmacol $84,577-584$.

Jiménez Hernández, J., Ragone, M.I., Bonazzola, P., Bandoni, A.L., Consolini, A.E., 2018. Bronchodilator, antitussive, antispasmodic and cardiac effect of the essential oil of Blepharocalyx salicifolius leaves. J. Ethnopharmacol. 210, 107-117.

Kenakin, T.P., 2014. A Pharmacology Primer. Techniques for More Effective and Strategic Drug Discovery, fourth ed., Elsevier, Amsterdam, pp. 134-138.

Kitchen, I., 1984. Textbook of in Vitro Practical Pharmacology, Blackwell Scientific Publications, Oxford, pp. 33-53.

Livingstone, E., Livingstone, S., 1970. Pharmacological Experiments on Isolated Preparations, second edition, Department of Pharmacology, University of Edinburgh, Edinburgh, pp.64-66 and pp. 92-95.

Matera, S., Piersante, M.V., Ragone, M.I., Consolini, A.E., 2012. Sedative and antispasmodic effects of Stevia rebaudiana and non-competitive inhibition of intestinal contractility by stevioside. Pharmacologyonline 1, 1-8.

Nishijima, S., Sugaya, K., Kadekawa, K., Naka, H., Miyazato, M., 2009. Comparison of the effect of anti-muscarinic agents on bladder activity, urinary ATP level, and autonomic nervous system in rats. Biomed. Res. 30, 107-112.

Petkov, G.V., 2011. Role of potassium ion channels in detrusor smooth muscle function and dysfunction. Nat. Rev. Uro1. 9, 30-40.

Philyppov, I.B., Golub, A.A., Boldyriev, O.I., Shtefan, N.L., Totska, K., Voitychuk, O.I., Shuba, Y.M., 2016. Myorelaxant action of fluorine-containing pinacidil analog, flocalin, in bladder smooth muscles mediated by inhibition of L-type calcium channels rather than activation of KATP channels. Naunyn Schmied.-Arch. Pharmacol. 389, 585-592.

Quast, U., 1993. Do the $\mathrm{K}^{+}$channel openers relax smooth muscle by opening $\mathrm{K}^{+}$channels? Trends Pharmacol. Sci. 14, 332-337.

Ragone, M.I., Sella, M., Conforti, P., Volonté, M.G., Consolini, A.E., 2007. The spasmolytic effect of Aloysia citriodora, Palau (South American cedrón) is partially due to its vitexin but not isovitexin on rat duodenums. J. Ethnopharmacol. 113, 258-66.

Rojano, B., Pérez, E., Figadère, B., Martín, M., Recio, M., Giner, R., 2007a. Constituents of Oxandra cf. xylopioides with antiinflammatory activity. J. Nat. Prod. 70, 835-838.

Rojano, B., Gaviria, M., Saéz, J., Yepes, F., Muñoz, F., Ossa, F., 2007b. Berenjenol aislado de Oxandra cf. xylopioides (Annonaceae) como insecticida. Vitae 14, 95-100.

Rojano, B., Saenz, J., Schinella, G., Quijano, J., Vélez, E., Gil, A., Notario, R., 2008. 
Experimental and theoretical determination of the antioxidant properties of isoespintanol (2-isopropyl-3,6-dimethoxy-5-methylphenol). J. Mol. Struct. 877, 1-6.

Sakakibara, F., Takahama, K., Nanri, M., Sasaki, E., 2016. Pharmacological properties of propiverine contribute to improving lower urinary tract dysfunctions in rats with spinal cord injuries. Drug Res. 66, 464-469.

Smith, R., McClure, M., Smith, M., Abel, P., Bradley, M., 2007. The role of voltage-gated potassium channels in the regulation of mouse uterine contractility. Reprod. Biol. Endocrinol. 5, 41-49.

Spedding, M., 1985. Competitive interactions between Bay K 8644 and nifedipine in $\mathrm{K}^{+}$ depolarized smooth muscle: a passive role for $\mathrm{Ca}^{2+}$. Arch. Pharmacol. 328, 464-466.

Sugaya, K., Nishijima, S., Kadekawa, K., Ashitomi, K., Yamamoto, H., 2012. Effect of distigmine combined with propiverine on bladder activity in rats with spinal cord injury. Int. J. Urol. 19, 480-483.

Tsabang, N., Valère, P., Fokoub, T., Yamthe, L., Noguema, B., Bakarnga-Viab, I., Dongmo, M., Aloys, N., Fekam, F., 2012. Ethnopharmacological survey of Annonaceae medicinal plants used to treat malaria in four areas of Cameroon. J. Ethnopharmacol. 139, 171-180.

Ultee, A., Bennik, M. H. J., Moezelaar, R., 2002. The phenolic hydroxyl group of carvacrol is essential for action against the food-borne pathogen Bacillus cereus. Appl. Environ. Microbiol. 68, 1561-1568.

Van Rossum, J.M., 1963. Cumulative dose-response curves. II Technique for the making of dose-response curves in isolated organs and the evaluation of drug parameters. Archiv. Intern. Pharmacodyn. Ther. 143, 299-330.

Zhao, Y., Wein, A.J., Levin, R.M., 1993. Role of calcium in mediating the biphasic contraction of the rabbit urinary bladder. Gen. Pharmacol. 24, 727-731.

.Zhuang, Y., Zhu, X., Huang, L., 2003. Antispasmodics and anticholinergics, in: Q.M. Neeshat (Eds.), Pharmaguide. Pharmaguide Publishing Company, 16, pp. 66-70. 


\section{Legend to the Figures:}

a<smiles>COc1cc(C)c(OC)c(O)c1C(C)C</smiles>

b<smiles>Oc1cc(O)cc(O)c1</smiles><smiles>COc1cc(OC)cc(OC)c1</smiles>

Fig. 1: Chemical structures of isoespintanol (a), phloroglucinol (b) and trimethoxybencene (c). 

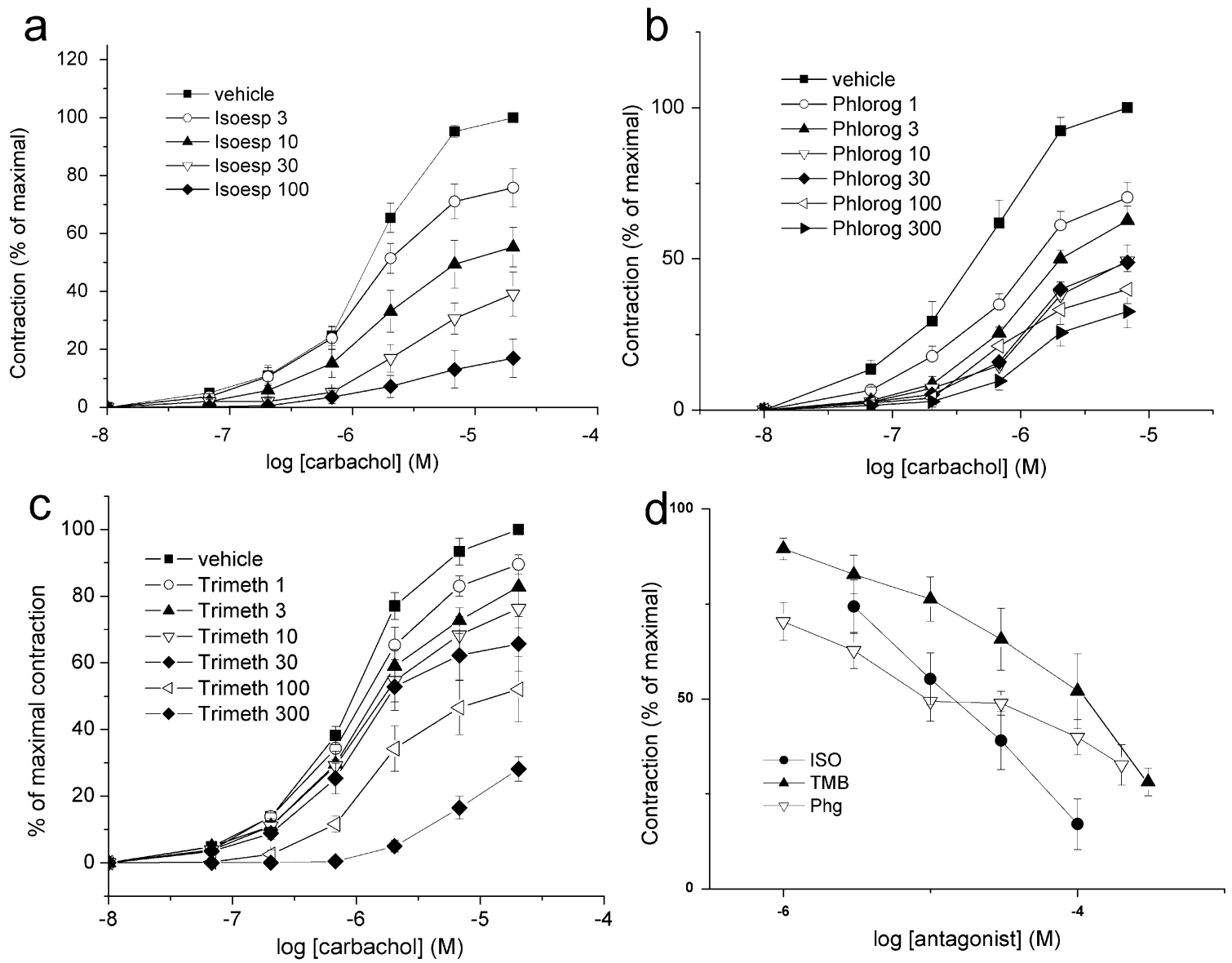

Fig. 2: Effects on rat isolated intestines: Concentration-contractile response curve (CRC) of 
carbachol in the absence and the presence of several concentrations (in $\mu \mathrm{M}$ ) of isoespintanol (a), phloroglucinol (b), and trimethoxybencene (c). The respective curves of inhibition are showed in (d) for comparing the $\mathrm{IC}_{50}$. Two way ANOVA: by treatment: $\mathrm{F}$ was $90.4,82.68$ and 81.28 respectively for $\mathrm{a}, \mathrm{b}$ and $\mathrm{c}$ (all $p<0.0001$ ); by log carbachol: $\mathrm{F}$ was 167.0, 339.5 and 397.3 respectively for $\mathrm{a}, \mathrm{b}$ and $\mathrm{c}($ all $p<0.0001)$.

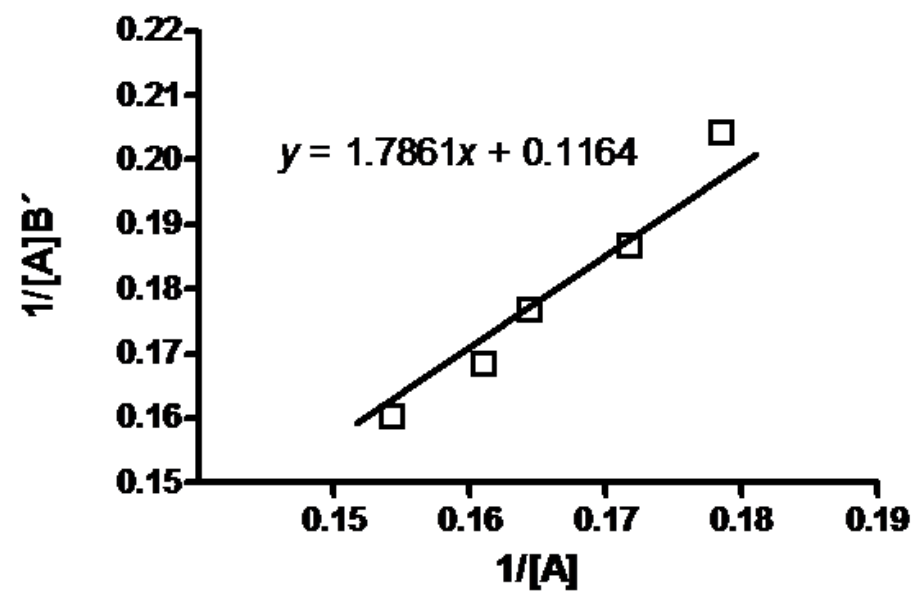

Fig. 3: Calculation of the affinity constant of the non-competitive antagonist isoespintanol on its own receptor by using the Gaddum method (data from the CRC shown in Fig. 2a). pK = 4.84 \pm 0.15. See description in section Methods ([A]: carbachol concentration, [A]-B': carbachol concentration in the presence of isoespintanol). 
a

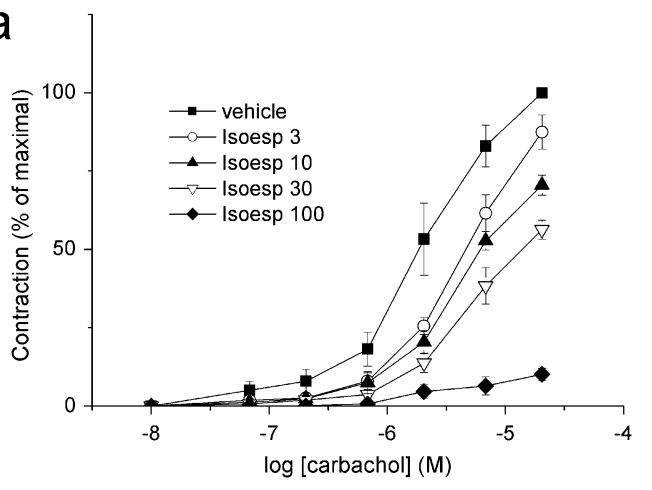

C

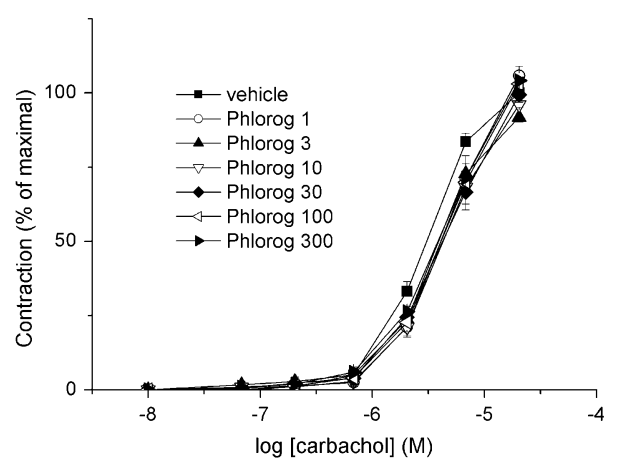

b

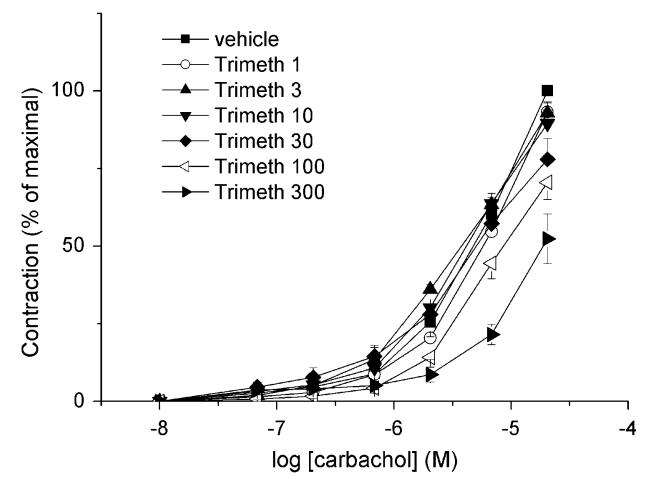

d

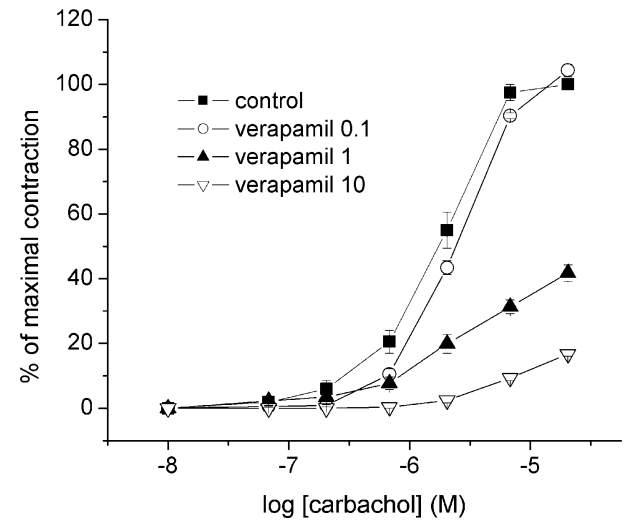

Fig. 4: Effects on rat isolated bladder strips: Concentration-contractile response curve (CRC) of carbachol in the absence and the presence of several concentrations (in $\mu \mathrm{M}$ ) of isoespintanol (a), trimethoxybencene (b), phloroglucinol (c) and verapamil (d). Results are 
showed as media \pm SEM. Two-way ANOVA: by treatment: F was 95.39, 28.01, and 589 respectively for $\mathrm{a}, \mathrm{b}$ and $\mathrm{d}$ (all $p<0.0001)$ and 1.6 for $\mathrm{c}(p>0.05)$; by log carbachol: $\mathrm{F}$ was 271.5, 964.7, 1138 and 896.7 respectively for a, b, c and d (all $p<0.0001$ ).

a

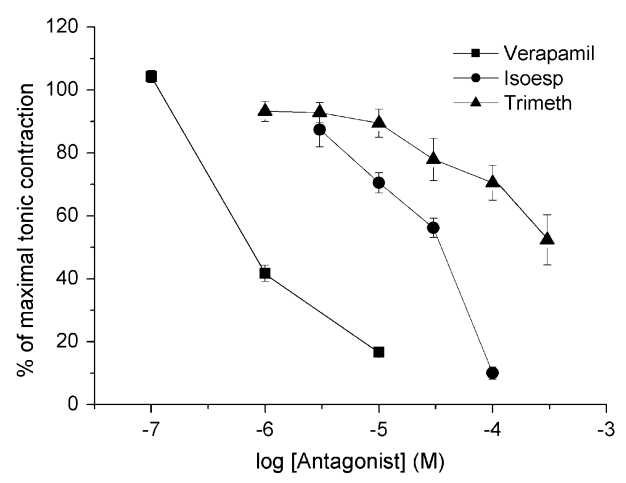

b
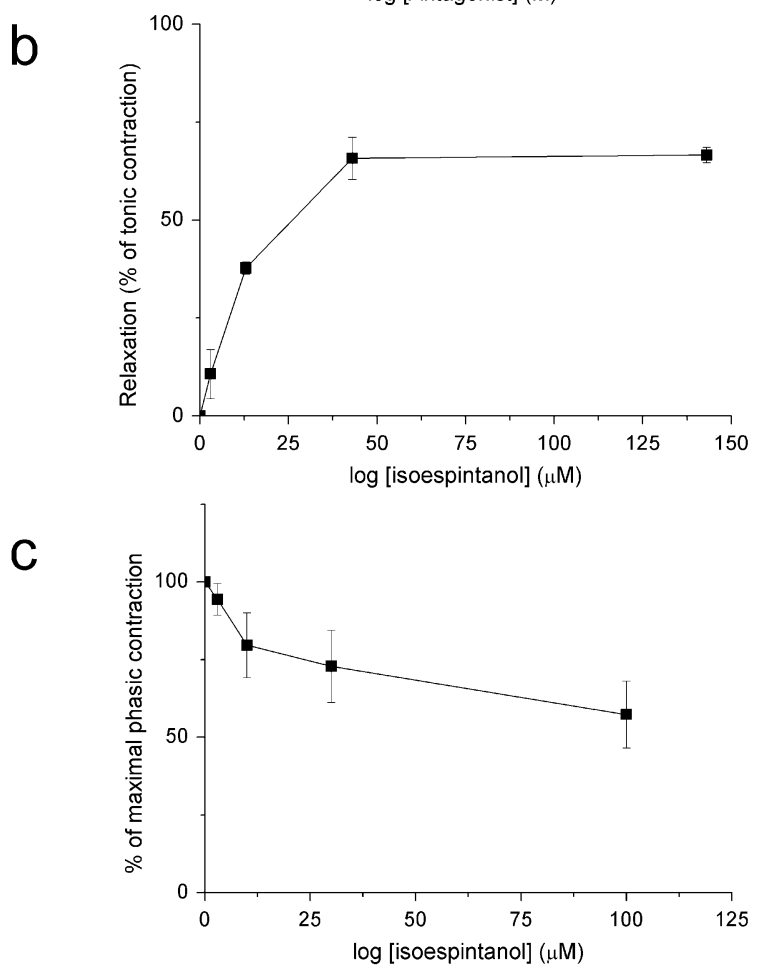
Fig. 5: Effects on bladder strips: Comparison of the inhibition curves of isoespintanol, trimethoxybenzene, and verapamil in the CRC of carbachol shown in Fig. 4 (a), of isoespintanol in the tonic contracture developed by carbachol after substracting the effect of vehicle DMSO (b), and isoespintanol on the phasic contractions induced by electrical field stimulation (c). The $\mathrm{IC}_{50}$ of isoespintanol were $38.64 \pm 3.1,11.5 \pm 0.5$, and $35.1 \pm 20 \mu \mathrm{M}$ respectively for $a(n=5), b(n=4)$ and $c(n=4)$. 

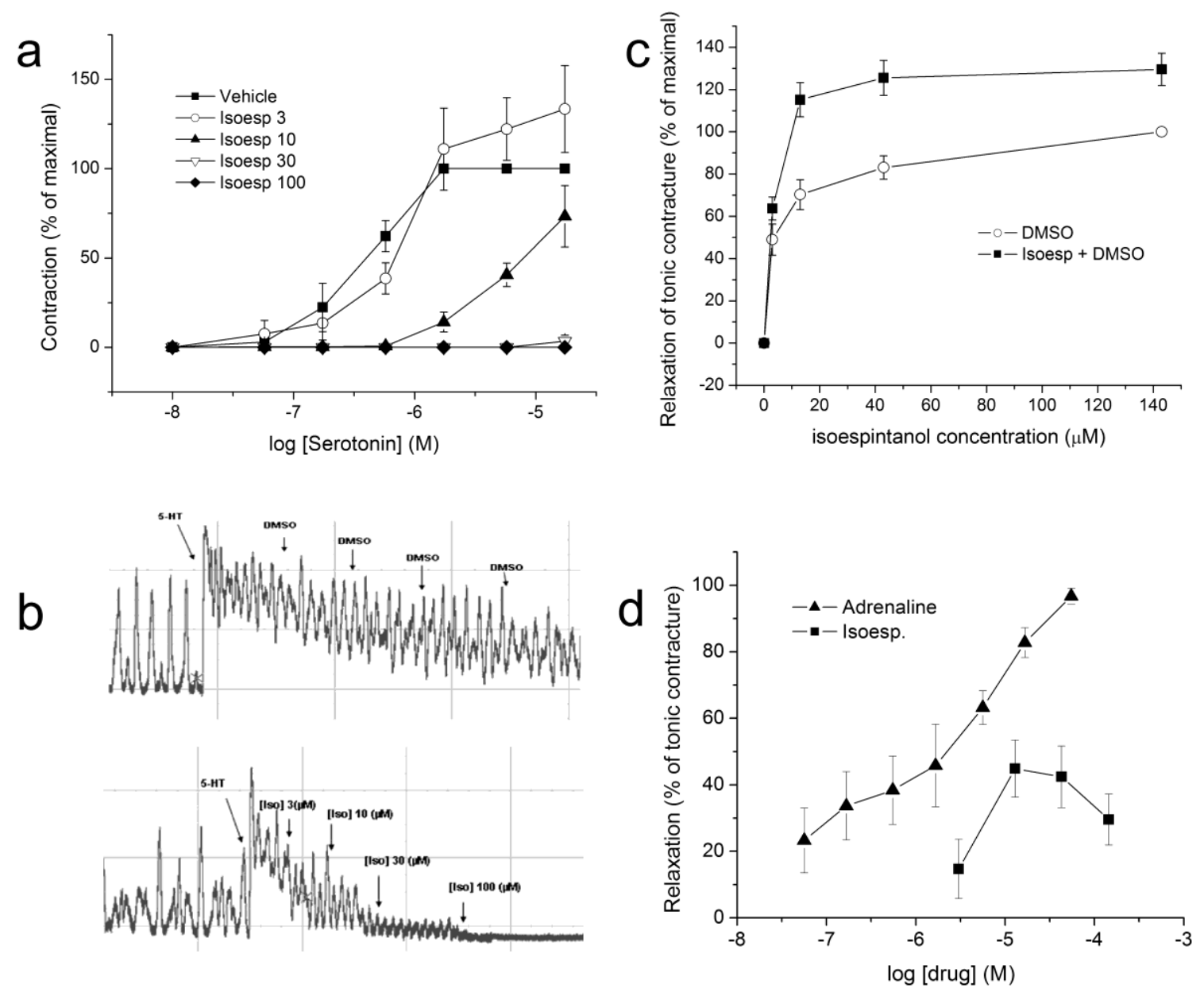

Fig. 6: Effects on rat isolated uterus: (a) Concentration-contractile response curves (CRC) of serotonin $(5-\mathrm{HT})$ in the absence and the presence of several concentrations of isoespintanol (in $\mu \mathrm{M}$ ) (two-way ANOVA: by treatment: $\mathrm{F}$ was $92.4(p<0.0001)$; by log [carbachol]: $\mathrm{F}$ was 
$50.71(p<0.0001)$. (b) Typical recordings of uterus contractions before and after adding 1 $\mu \mathrm{g} / \mathrm{ml} 5$-HT and subsequent addition of either DMSO (upper) or growing concentrations of isoespintanol (lower). (c) Inhibition curves of DMSO and isoespintanol + DMSO; (d) Comparison between inhibition curves of adrenaline and isoespintanol (after substracting the DMSO effect).

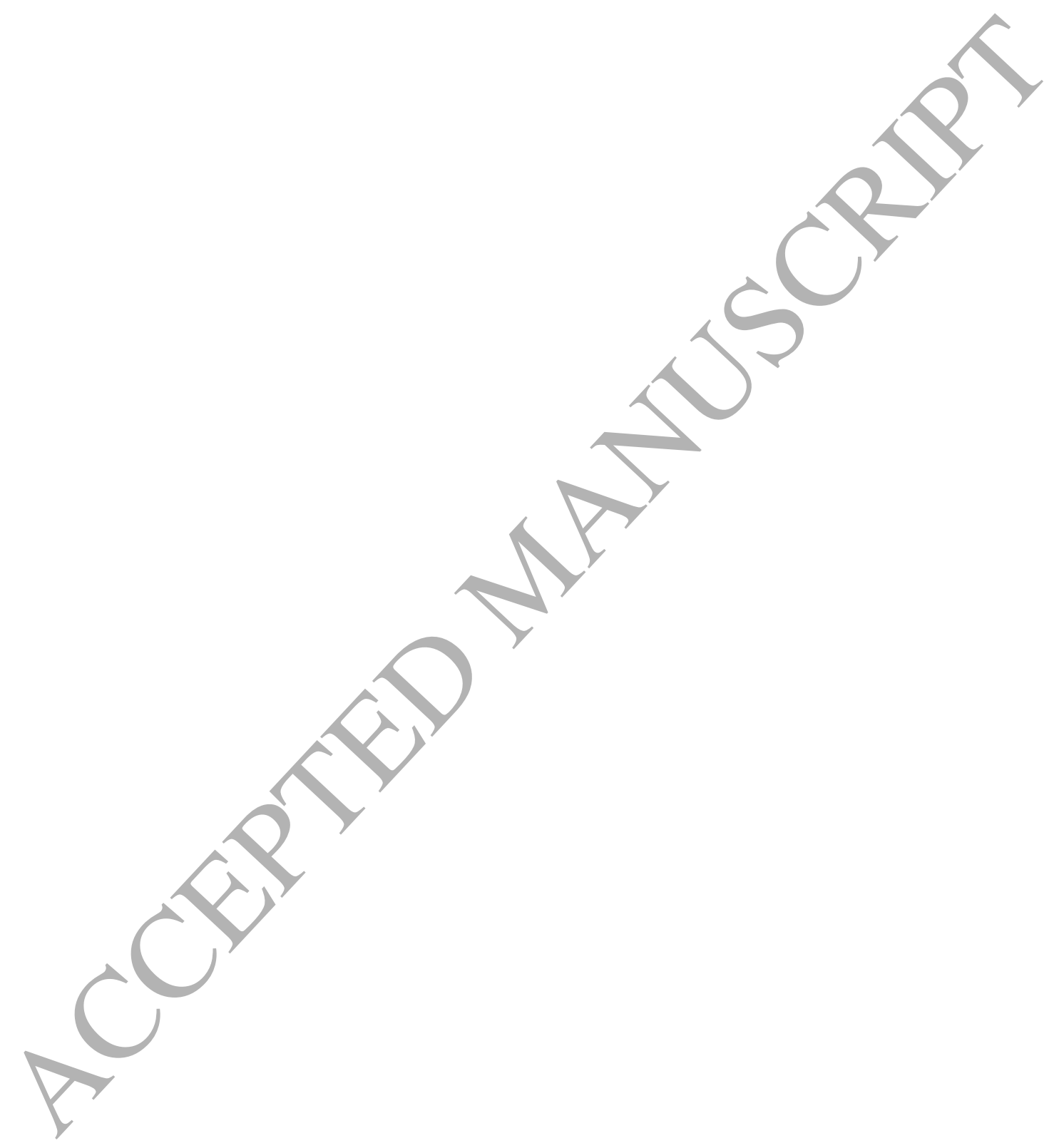


a

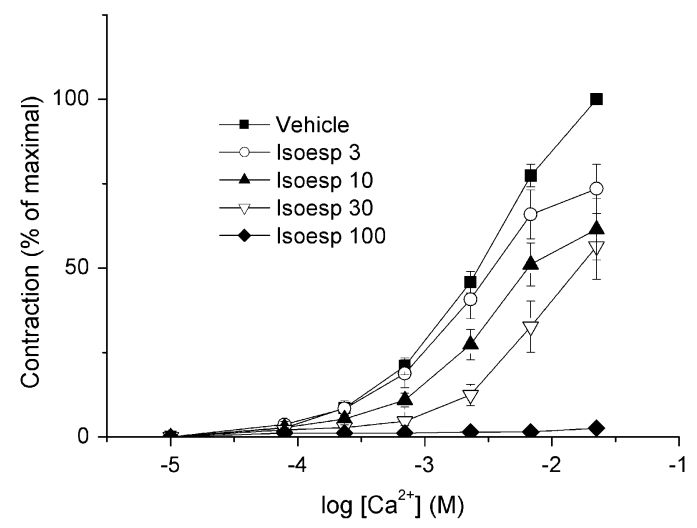

b

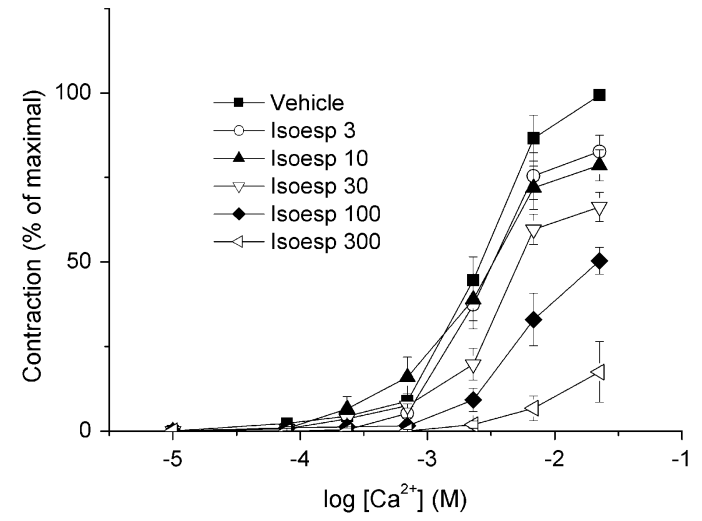

C

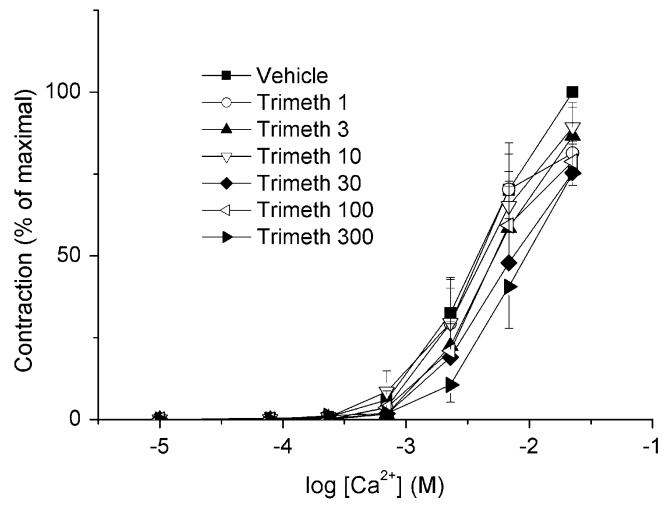

Fig. 7: Effects on calcium: Concentration-contractile response curve of $\mathrm{Ca}^{2+}$ in Tyrode- 0 $\mathrm{Ca}^{2+}-40 \mathrm{mM} \mathrm{K}{ }^{+}$media, in the absence and the presence of several concentrations of isoespintanol in rat intestines (a) and bladder (b), and in the presence of trimethoxybencene in 
bladder (c). The antagonists concentration are expressed in $\mu \mathrm{M}$. Two-way ANOVA: by treatment: F was 89.14, 51.5 respectively for a and b (both $p<0.0001)$ and 2.46 for $\mathrm{c}(p<$ 0.05); by $\log$ [carbachol]: $\mathrm{F}$ was $182.5,280$ and 176.3 respectively for $\mathrm{a}, \mathrm{b}$ and $\mathrm{c}$ (all $p<$ $0.0001)$.

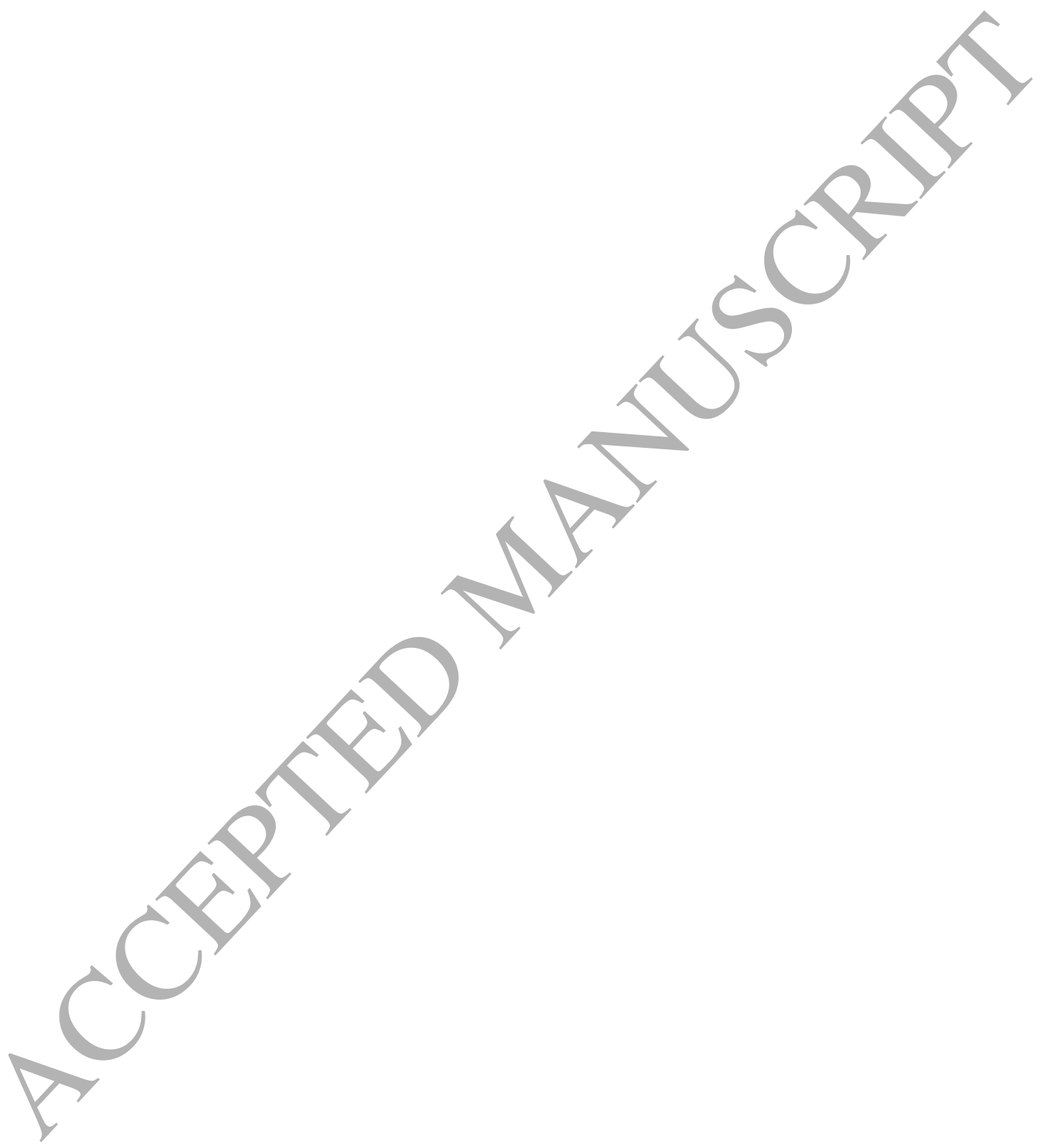


Table 1. Comparison of the affinity constants obtained by the traditional method ( $\left.\mathrm{pD}^{\prime} 2\right)$ and by the Gaddum method with linear regression $(\mathrm{pK})$ for the non-competitive antagonists isoespintanol (ISO) and verapamil in the protocols assessed by means of CRC in different tissues and agonists.

\begin{tabular}{|c|c|c|c|c|c|}
\hline Tissue & Antagonist & $\begin{array}{c}\text { [Antagonist] } \\
(\mu \mathrm{M})\end{array}$ & Agonist & $\begin{array}{l}\text { pK by Gaddum } \\
\text { method }\end{array}$ & $\begin{array}{c}\text { pD'2 } \\
\text { traditional } \\
\text { method }\end{array}$ \\
\hline \multirow[b]{4}{*}{ Intestine } & \multirow[b]{2}{*}{ isoespintanol } & 10 & $\mathrm{Cbl}$ & $4.84 \pm 0.15(n=4)$ & $4.78 \pm 0.09(n=29)$ \\
\hline & & 10 & $\mathrm{Ca}^{+2}$ & $4.65 \pm 0.15(\mathrm{n}=5)$ & $5.10 \pm 0.10(\mathrm{n}=36)$ \\
\hline & \multirow[b]{2}{*}{ Verapamil $^{\mathrm{a}}$} & 0.1 & $\mathrm{Cbl}$ & $6.17 \pm 0.16(\mathrm{n}=4)^{\mathrm{a}}$ & $6.22 \pm 0.15(n=19)$ \\
\hline & & 0.1 & $\mathrm{Ca}^{+2}$ & $6.64 \pm 0.28(\mathrm{n}=4)^{\mathrm{a}}$ & $6.50 \pm 0.11(n=10)$ \\
\hline \multirow{4}{*}{ Bladder } & \multirow[b]{2}{*}{ isoespintanol } & 30 & $\mathrm{Cbl}$ & $4.54 \pm 0.04(n=4)$ & $4.60 \pm 0.09(n=20)$ \\
\hline & & 100 & $\mathrm{Ca}^{+2}$ & $4.23 \pm 0.06(\mathrm{n}=4)$ & $4.32 \pm 0.07(n=29)$ \\
\hline & Verapamil & 1 & $\mathrm{Cbl}$ & $6.06 \pm 0.05(\mathrm{n}=4)$ & $5.80 \pm 0.13(\mathrm{n}=9)$ \\
\hline & isoespintanol & 10 & 5-HT & $5.40 \pm 0.20(\mathrm{n}=5)$ & $5.05 \pm 0.06(n=5)$ \\
\hline
\end{tabular}

See description of the methods in the respective section. Cbl: carbachol, 5-HT: serotonin

${ }^{\mathrm{a}}$ From Blanco et al., 2013. 
Graphical abstract
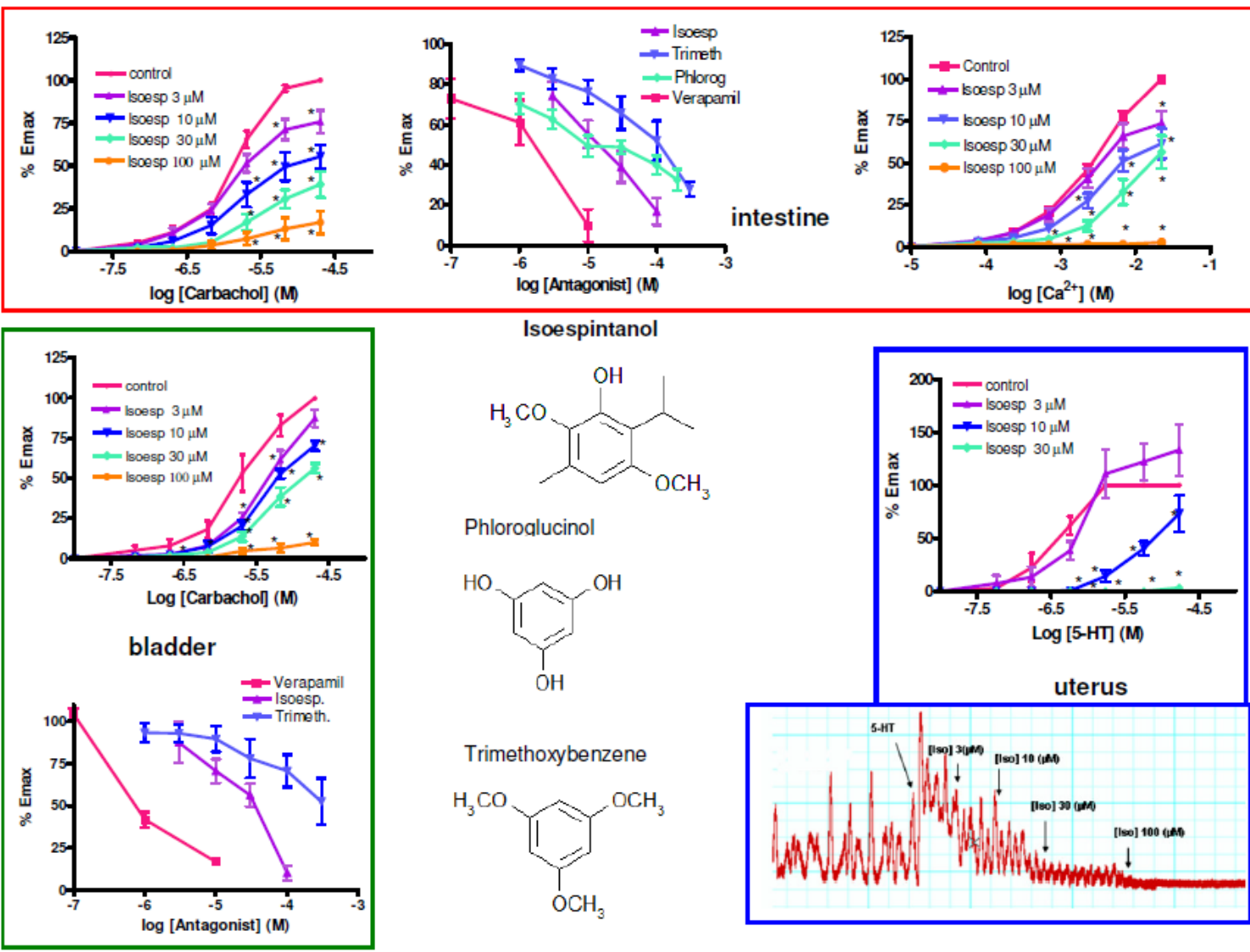

Isoespintanol

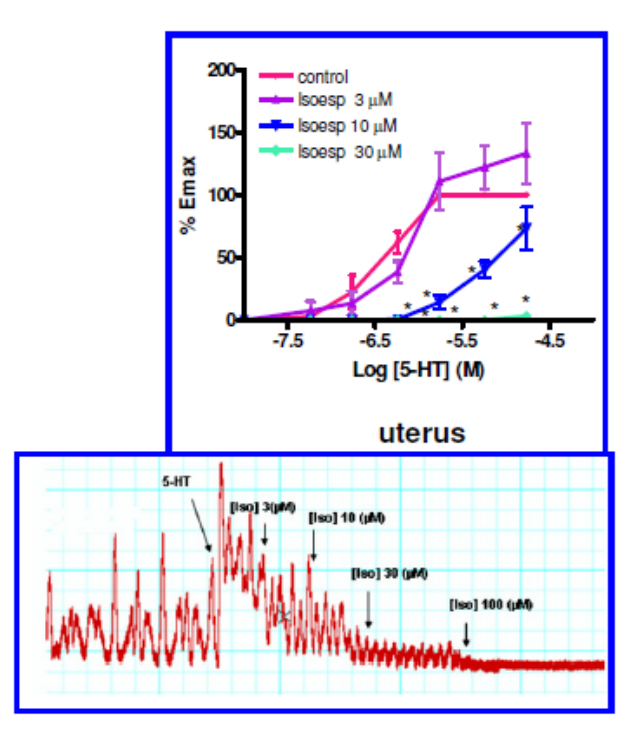

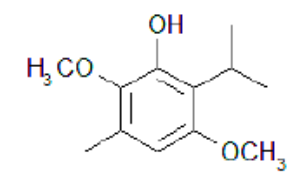

Phloroglucinol

$\mathrm{HO}$<smiles>Cc1cc(O)cc(O)c1</smiles>

Trimethoxybenzene

$\mathrm{H}_{3} \mathrm{CO}$<smiles>COc1cccc(OC)c1</smiles> 